\title{
OPINIE
}

\section{Onafhankelijkheid en onpartijdigheid in de rechtswetenschap*}

\author{
Rob van Gestel
}

\section{Dubbele petten in de rechtswetenschap}

Recent is naar aanleiding van de oratie van Vleggeert opnieuw discussie ontstaan over de vele hoogleraren fiscaal recht met dubbele petten. ${ }^{1}$ Hij betoogt onder andere dat bepaalde onderwerpen in de literatuur niet of nauwelijks ter sprake komen, omdat deze conflicteren met de belangen van de kantoren en cliënten waarvoor het gros van de fiscalisten buiten de wetenschap werkzaam is. ${ }^{2}$ Het is niet voor het eerst dat deze discussie speelt. In 2016 is dit punt ook al eens in de publiciteit gekomen als gevolg van onderzoek door de Volkskrant. ${ }^{3}$ Staatssecretaris Wiebes reageerde destijds op dat onderzoek door te stellen:

'Het risico op belangenverstrengeling valt nooit helemaal uit te sluiten maar er zijn volgens ons genoeg voorzieningen in het systeem om er voor te zorgen dat hoogleraren hun onafhankelijkheid behouden. Hoogleraren zijn immers gehouden aan het naleven van de normen uit de Nederlandse Gedragscode Wetenschapsbeoefening waaronder de daarin vastgelegde principes "onafhankelijkheid" en "onpartijdigheid". Ook dienen zij hun nevenfuncties te vermelden op de website van de universiteit. De besturen van de universiteiten zien erop toe dat de gedragscode wordt nageleefd en de vermelding van nevenfunc-

* Dit opiniestuk van Rob van Gestel is tot stand gekomen aan de hand van het "Dubbele pettencongres" dat op 24 September 2021 in Leiden werd gehouden.

1 J. Vleggeert, Hoe onafhankelijk is de fiscale wetenschapper?, (oratie, Universiteit Leiden, 2020 (https:// www.universiteitleiden.nl/nieuws/2020/11/terugkijken-oratie-jan-vleggeert---hoe-onafhankelijkis-de-fiscale-wetenschapper).

2 D. Notenboom \& W.R. Kooiman, 'Hoogleraren met een dubbele pet onafhankelijk?', NLF-W 30 (2021): 1-15 (https://www.nlfiscaal.nl/nlfw2021/0030) komen op grond van empirisch onderzoek, anders dan Vleggeert, tot de conclusie dat niet bewezen kan worden dat hoogleraren met een dubbele pet vooral in het belang van hun clientèle schrijven. Wel constateren zij echter dat het opvallend is: 'waarover niet wordt geschreven. Als het geldende recht positief uitpakt voor de belastingplichtige maar deze uitkomst niet gewenst is, bijvoorbeeld omdat er sprake is van een heffingslek, klimmen hoogleraren met dubbele pet opvallend weinig in de pen'. Daarnaast zien zij eenzijdigheid in de onderwerpen waarover wordt gepubliceerd. De nadruk ligt op de belastingheffing van bedrijven. De belastingheffing van particulieren krijgt, ondanks de grote maatschappelijke relevantie, veel minder aandacht, maar dat zou zowel voor hoogleraren met als zonder dubbele pet gelden.

3 Zie 'Belastingprofessoren zelden volledig onafhankelijk', de Volkskrant, 21 mei 2016. 
ties plaatsvindt. Wij spreken de besturen van de universiteiten vervolgens aan op hun verantwoordelijkheid."

Hoe besturen van universiteiten precies op de naleving van de gedragscode moeten toezien als hoogleraren hun nevenwerkzaamheden niet correct vermelden, zegt de staatssecretaris er niet bij. Dat dit geregeld mis gaat, was kort daarvoor al gebleken uit onderzoek door journalisten van De Groene Amsterdammer die ontdekten dat nevenwerkzaamheden en neveninkomsten van hoogleraren vaak niet correct worden opgegeven aan de universiteit. ${ }^{5}$ Hoe gemakkelijk dat tot problemen kan leiden, bleek recentelijk ook nog weer eens in de zaak over de Groningse hoogleraar Kochenov die betaalde adviezen verleende aan de Maltese overheid, welke zich bezighield met omstreden paspoorthandel. Kochenov had deze neveninkomsten niet opgegeven. Een onderzoekscommissie, ingesteld door minister van Engelshoven, gaf vervolgens niet alleen de hoogleraar een tik op de vingers, maar ook de RUG die 'consequent en minder terughoudend' over nevenwerkzaamheden met de betrokken hoogleraar had kunnen spreken. ${ }^{6}$

De zojuist genoemde voorbeelden tonen aan dat commerciële invloeden een bedreiging kunnen vormen voor de (schijn van) onafhankelijkheid van rechtswetenschappers. Zeker in tijden waarin politici elkaar bestoken met alternative facts, de media worden beticht van fake news ${ }^{7}$ en er veel discussie is over de invloed van onder andere big tech bedrijven op wetenschappelijk onderzoek, ${ }^{8}$ zouden ook rechtswetenschappers die vaak dicht tegen de praktijk aan schuren niet naïef mogen zijn waar het gaat om de kwetsbaarheid van hun reputatie en positie. Maar in deze bijdrage wil ik echter ook laten zien dat het 'dubbelepettenprobleem' onderdeel is van een bredere problematiek die betrekking heeft op een gebrek aan aandacht binnen de rechtswetenschap voor de onafhankelijkheid en onpartijdigheid van juridisch onderzoek. Daartoe zal ik om te beginnen (par. 2) betogen dat er binnen de rechtswetenschap weliswaar vanouds veel aandacht bestaat voor problemen rond onafhankelijkheid en onpartijdigheid van de rechter, maar dat diezelfde belangstelling nagenoeg ontbreekt waar het om rechtswetenschappers zelf gaat. Daarbij zal ik een mogelijke verklaring bieden waarom dit het geval is. Vervolgens wil ik aan de hand van voorbeelden aannemelijk maken dat er enige reden is tot zorg (par. 3). Daarna bekijk ik hoe de onafhankelijkheid en onpartijdigheid van rechtswetenschappers momenteel geborgd is, waarbij ik aandacht schenk aan de VSNU-gedragscode wetenschappelijke integriteit (par. 4). Onafhankelijkheid en

$4 \quad$ Handelingen II 2015-2016, aanhangsel 2890.

5 Zie: https://www.groene.nl/artikel/ondernemende-professoren.

6 Onderzoekscommissie Van Keulen, Verslag van onderzoek naar nevenwerkzaamheden en nevenbelangen van prof. dr. D. Kochenov en de rol van de Rijksuniversiteit Groningen daarbij Groningen 29 april 2020, 44. (https://www.rug.nl/about-ug/latest-news/news/archief2020/bijlagen/ onderzoeksrapport-kochenov-def.pdf). Zie ook: https://nos.nl/nieuwsuur/artikel/2336629paspoorthandel-groningse-hoogleraar-schuldig-aan-belangenverstrengeling.

7 S. Neubert \& K. Reich, 'Chapter 5: Fake News and Alternative Facts - A Constructivist Critique of the Current Right-Wing Populist Will to Truth', International Research in Higher Education 3, nr. 1 (2018): 70-76.

8 F. Boer, 'What Big Tech Wants Out of the Pandemic', The Atlantic, July/August 2020. 
onpartijdigheid worden in die code, anders dan in de code van onze zuiderburen, niet duidelijk onderscheiden. Bovendien biedt de code vaak weinig houvast met betrekking tot de vraag wat de normen in de praktijk nu precies voor (rechts)wetenschappers zouden moeten betekenen en welke invloed en verantwoordelijkheid anderen, zoals universitaire bestuurders, opdrachtgevers van contractonderzoek, uitgevers en tijdschriftredacties, op de naleving ervan hebben. In aansluiting daarop zal ik (par. 5) verdedigen dat en waarom, hoewel onafhankelijkheid en onpartijdigheid niet volledig te scheiden zijn, het onderscheiden daarvan wel van belang is, al was het maar vanwege het feit dat er deels verschillende waarborgen nodig zijn om aantasting van deze beginselen van behoorlijke wetenschap tegen te gaan. Ik besluit (par. 6) met het trekken van enkele conclusies.

\section{Eenzijdige focus op de rechter}

Dat rechters onafhankelijk en onpartijdig moeten zijn, is algemeen geaccepteerd en daar is vanouds veel aandacht voor in de rechtswetenschap. Er zijn niet alleen tal van wettelijke regels, procedures en controlemechanismen om deze waarborgen in de praktijk te garanderen, maar er is ook ontstellend veel literatuur over. ${ }^{9}$ Het is derhalve weinig verrassend dat er grote opwinding is in de rechtswetenschap wanneer de onafhankelijkheid en onpartijdigheid van rechters in het gedrang komen, zoals we recent hebben gezien in Polen en Hongarije, waar regeringen de aanval hebben geopend op de rechterlijke macht. ${ }^{10}$ Op zichzelf is dit niet verwonderlijk aangezien dit soort problemen de kern van de rechtsstaat raken, namelijk de bescherming van de burger tegen de overheid op een manier die tevens een fair trial als bedoeld in artikel 6 EVRM garandeert. Niemand zal met andere woorden willen ontkennen dat de onafhankelijkheid en onpartijdigheid van rechter belangrijk zijn.

Toch geldt dat ook de onafhankelijkheid en onpartijdigheid van rechtswetenschappers essentieel zijn. Niet alleen leiden zij toekomstige generaties juristen op en zou het slecht zijn als dat zou gebeuren op een sterk ideologisch gekleurde manier of beïnvloed door niet-wetenschappelijke belangen, ${ }^{11}$ maar zij becommentariëren ook rechterlijke uitspraken in publicaties en doen tevens met regelmaat aanbeve-

9 Zie uit velen: F. van Dijk, Perceptions of the independence of judges in Europe: congruence of society and judiciary (eBook, Palgrave Macmillan, 2021); S. Shetreet \& W. McCormack (eds.), The culture of judicial independence in a globalised world (eBook, Leiden; Boston: Brill Nijhoff, 2016); P.M. van den Eijnden, Onafhankelijkheid van de rechter in constitutioneel perspectief, (Deventer: Kluwer, 2011); J.B.J.M. ten Berge \& A.M. Hol., De onafhankelijke rechter (Den Haag: Boom Juridische uitgevers, 2007); P. Van Orshoven, L.F.M. Verhey \& K. Wagner, De onafhankelijkheid van de rechter (Deventer: W.E.J. Tjeenk Willink, 2001).

10 Vgl. o.a. J. Morijn, 'De EU en de rechtsstatelijke crises in Hongarije en Polen', NJB 3 (2021): 200206; G. Corstens, 'De rechtsstaat, hier en in Polen en Hongarije', NTM/NJCM-Bull. 43, nr. 3 (2018): 473-480; K. Sterk, F. van Dijk \& B. Diephuis, 'Hoe staat het met de onafhankelijkheid van de rechtspraak in de Unie?', NJB 28 (2019): 2010-2018.

11 Vergelijk ook het belang van een extern perspectief van de rechtswetenschapper dat niet wordt beheerst door deelbelangen, zoals o.a. bepleit door R. Cotterell, Sociological Jurisprudence: Juristic Thought and Social Inquiry (Abingdon, Oxon; New York, 2018). 
lingen voor verbetering van het geldende recht die vaak met graagte worden overgenomen door de wetgever en de rechter. Wie evenwel gaat zoeken naar literatuur over onafhankelijkheid en onpartijdigheid van rechtswetenschappers vindt: a) bitter weinig, b) ontdekt al snel dat er geen wettelijk integriteitsregels voor hen bestaan, en c) dat van een actief toezichts- en handhavingsbeleid op de naleving van wetenschappelijke gedragscodes al evengoed geen sprake is. ${ }^{12}$ Als er bovendien al eens een kwestie opduikt, dan wordt dat dikwijls afgedaan als een incident dat de individuele verantwoordelijkheid is van de betreffende wetenschapper en diens werkgever. ${ }^{13}$

De verklaring voor de eenzijdige gerichtheid van rechtswetenschappers op de onafhankelijkheid en onpartijdigheid van de rechter houdt ongetwijfeld verband met de observatie van Vranken dat rechtswetenschappers überhaupt moeite hebben om zich los te maken van het rolmodel van de rechter. ${ }^{14}$ Dat is bijvoorbeeld terug te zien in de weinig geëxpliciteerde tekstanalytische en argumentatieve methoden die rechtswetenschappers gebruiken, welke doorgaans sterke overeenkomsten vertonen met die van de rechter. Het is ook te herkennen aan hun gerichtheid op casus, op overtuigingskracht en op verbetering van het geldende recht.

Er zijn niettemin ook duidelijke verschillen tussen de mate waarin en wijze waarop de onafhankelijkheid en onpartijdigheid van de rechter en van de wetenschapper geregeld zijn. Zo worden rechters voor het leven benoemd, maar geldt dat niet voor rechtswetenschappers. ${ }^{15}$ Daarnaast zijn er tal van wettelijke regels en procedures die de onafhankelijkheid en onpartijdigheid van rechters moeten borgen, zoals formele benoemingsregels, wrakingsprocedures en regelgeving voor de waardering van bewijs, terwijl in de rechtswetenschap voornamelijk op zelfregulering wordt vertrouwd, hoewel we inmiddels weten dat de huidige zelfreguleringsmechanismen vaak niet in staat zijn om fraude of andere integriteitsschendingen tegen te gaan. ${ }^{16}$

De vraag die zich derhalve opdringt is: valt de geringe belangstelling van rechtswetenschappers voor mogelijke problemen met betrekking tot hun eigen onafhankelijkheid en onpartijdigheid in vergelijking tot die van de rechter louter te verklaren doordat er minder bedreigingen zijn op dit punt voor rechtswetenschappers?

12 Stolker constateerde in een veelbesproken Diesrede jaren geleden reeds dat er in de rechtswetenschap veel belangstelling is voor 'de persoon van de rechter' en bijvoorbeeld de vraag of eenzelfde persoon de functies van advocaat én rechter kan combineren, maar dat nog betrekkelijk weinig belangstelling bestaat voor 'de persoon van de onderzoeker'. Hij vroeg zich toen al af: 'Is er binnen de faculteiten wel voldoende aandacht voor de vraag naar de onafhankelijkheid van de hoogleraar?' Zie: C. Stolker, “Ja, geléérd zijn jullie wel!” Over de status van de rechtswetenschap', NJB 2003: 772.

13 Zie het bovengenoemde voorbeeld aan de RUG van hoogleraar Kochenov.

14 J.B.M. Vranken, Algemeen Deel. Een synthese (Deventer: Kluwer, 2014), die er terecht op wijst dat dit niet louter een Nederlands verschijnsel is. Wetenschappelijke boeken over "Thinking like a lawyer", zoals het gelijknamige boek van F. Schauer, gaan zelden primair over hoe rechtswetenschappers denken.

15 Art. 117 van de Grondwet.

16 W. Stroebe, T. Postmes \& R. Spears, 'Scientific Misconduct and the Myth of Self-Correction in Science', Perspectives on Psychological Science 17, nr. 6 (2012): 670-688. 
Anders gezegd, mogen de zeldzame gevallen van schending die in de openbaarheid komen, worden beschouwd als bewijs voor het feit dat het met de onafhankelijkheid en onpartijdigheid van rechtswetenschappers in Nederland wel goed zit? ${ }^{17}$

\section{Zijn bestaande problemen rond de onafhankelijkheid en onpartijdigheid in de rechtswetenschap incidenten?}

Problemen rond de onafhankelijkheid en onpartijdigheid binnen de rechtswetenschap beperken zich helaas niet tot de dubbelepettenproblematiek.

\subsection{Onafhankelijke rechtswetenschap}

Brenninkmeijer heeft eerder gewezen op het gevaar dat geldverstrekkers steeds meer de inhoud van onze onderzoeksagenda bepalen en dat de toenemende afhankelijkheid van projectfinanciering tevens het risico met zich brengt dat niet alleen wordt geconcurreerd op de kwaliteit, maar ook op de plooibaarheid van de vraagstelling, methode en verslaglegging. ${ }^{18}$ Dit gevaar is allerminst nieuw, ${ }^{19}$ maar recent ook nog eens duidelijk geworden naar aanleiding van de problemen die we hebben gezien bij het wetenschappelijk onderzoeks- en documentatiecentrum van het ministerie van Justitie en Veiligheid (WODC) waar sprake was van beïnvloeding van de uitkomsten van wetenschappelijk onderzoek in een politiek gewenste richting. ${ }^{20}$

Dit laatste roept niet enkel vragen op over de integriteit van de opdrachtgever maar, indien beïnvloedingspogingen slagen, evengoed over de onafhankelijkheid van de wetenschappers die kennelijk soms bereid zijn onwelgevallige resultaten achterwege te laten. Vragen kunnen zelfs worden gesteld over de onafhankelijkheid van redacties van juridische tijdschriften en boeken. Zijn uitgevers van juridische boeken wel altijd zo geïnteresseerd in de kwaliteit van de inhoud of is de verwachte oplage een doorslaggevende factor bij beslissingen over publicatie? ${ }^{21}$ En hoe staat het met de samenstelling van tijdschriftredacties? Wie zorgt daar dat bepaalde commerciële of andere belangen niet doorslaggevend worden? Een prominent voorbeeld is het European Law Journal $(E L J)$ waarbij eerder de voltallige redactie van het tijdschrift is opgestapt uit onvrede over de invloed die de uitgever

17 Opvallend is bijvoorbeeld dat uit de resultaten van de grootste nationale enquête naar wetenschappelijke integriteit in Nederland tot nog toe naar voren komt dat er veel vaker problemen zijn met de wetenschappelijke integriteit dan voorheen gedacht. Zo geeft ruim de helft van de respondenten aan regelmatig tegen wetenschappelijke integriteitsregels te zondigen door onwelgevallige onderzoeksresultaten weg te laten, problemen met de methodiek van een studie te verzwijgen of selectief te citeren uit de beschikbare literatuur. Ruim $8 \%$ heeft de afgelopen drie jaar zelfs onderzoeksresultaten verzonnen of vervalst. Zie voor de resultaten: https://www.nsri2020.nl/.

18 A. Brenninkmeijer, 'Wie betaalt, bepaalt!', NJB 1854 (2008): 2355.

19 KNAW-werkgroep opdrachtonderzoek, Wetenschap op bestelling. Over de omgang tussen wetenschappelijk onderzoekers en hun opdrachtgevers (Amsterdam: KNAW, 2005).

20 Daarover o.a.: Onderzoekscommissie WODC II, Ongemakkelijk onderzoek. Naar een betere balans in de relatie tussen WODC en beleid, Den Haag 15 januari 2019.

21 Ik heb zelf eerder gewezen op de vaak belabberde en willekeurige staat van de kwaliteitscontrole bij juridische tijdschriften en uitgevers van juridische boeken. Zie: R.A.J. van Gestel, Kwaliteit van juridische publicaties, Preadvies NJV (Deventer: Kluwer, 2015) 243 e.v. 
probeerde uit te oefenen op de samenstelling van de redactie en op het redactionele beleid. ${ }^{22}$

Een andere bedreiging van de onafhankelijkheid zien we op het gebied van de inmenging in wat in de VS bekend staat als free speech on campus. ${ }^{23}$ Niet lang geleden hebben we in Tilburg nog gezien dat een wetenschapper die een kritische column over de \#metoo-beweging in de universiteitskrant schreef, ${ }^{24}$ bedolven werd onder de protesten van wetenschappers die nota bene onder het mom van de universiteit als safe space het College van Bestuur opriepen in te grijpen. ${ }^{25}$ Dat gebeurde vervolgens ook. Zowel de mannelijke columnist als de vrouwelijke hoofdredactrice van Univers, die hem had beschermd, kregen van datzelfde bestuur een reprimande dat plaatsing van dergelijke columns in strijd zou zijn met de code of conduct van de universiteit. ${ }^{26}$ Hier is ook protest tegen gekomen, ${ }^{27}$ maar het laat zien hoe gemakkelijk je als wetenschapper onder collegiaal en bestuurlijk vuur kunt komen te liggen. Wie denkt dat dit een unieke situatie is, wijs ik op een andere recente actie van het College van Bestuur van de Erasmus Universiteit dat de emails van wetenschappers, die verdacht werden van contacten met de pers over de vermeende plagiaat van interim-decaan (tevens voormalig UvA-rector) Van den Boom, liet screenen door een bedrijfsrecherchebureau. ${ }^{28}$ Uiteindelijk heeft het bestuur van de universiteit daarvoor excuses aangeboden, maar pas nadat er een uitgebreide protestactie op gang was gekomen..$^{29}$

Hiermee zijn we gelijk bij een tot op heden onderbelichte invalshoek beland. Dat is de beïnvloeding van de onafhankelijke wetenschapsbeoefening door universiteiten zelf. Zo constateert Groen dat universiteitsbesturen steeds meer invloed uitoefenen op de opleidingen. ${ }^{30}$ Colleges van Bestuur nemen, al dan niet gedwongen door

22 Zie: http://www.iconnectblog.com/2020/02/wiley-and-the-european-law-journal/.

23 E. Chemerinsky \& H. Gillman, Free Speech on Campus (Yale University Press: New Haven and London, 2017).

24 H. Verbon, '\#Nomoremetoo', Univers 3 november 2017 (https://universonline.nl/nieuws/2017/11/03/ nomoremetoo/).

25 Op de gedachte dat je ook een kritische tegenreactie zou kunnen schrijven op de column voor dezelfde universiteitskrant kwamen de wetenschappelijke 'indignado's' kennelijk niet.

26 De hoofdredactrice van Univers heeft uiteindelijk het veld moeten ruimen. Zij was wel vaker kritisch en pleitte bijvoorbeeld namens de kring van hoofdredacteuren ook voor onafhankelijke financiering van universiteitskranten. Zie Ad Valvas, 28 november 2017 (https://www.advalvas.vu.nl/nieuws/ censuurkwestie-we-staan-allemaal-onder-druk-dat-gewoon-zo).

27 Zie o.a. de vlijmscherpe column van E. Drayer, 'Ook hier begint de mallotige term "safe space" wortel te schieten', de Volkskrant, 16 februari 2018. Zie ook L. van Gelder, 'De universiteit is geen safe space', Univers 12 april 2018 met o.a. interviews met Paul Frissen en Jan Vranken, waarbij laatstgenoemde sprak over een angstcultuur aan de universiteit waar het gaat om het geven van kritiek.

28 Zie: https://www.erasmusmagazine.nl/2019/09/18/forensisch-bureau-doet-onderzoek-naarplagiaatlek-bij-eshcc/ en https://www.folia.nl/actueel/132641/erasmus-universiteit-vindt-lek-inzaak-van-den-boom-niet.

29 Zie: https://www.erasmusmagazine.nl/2020/01/15/college-biedt-toch-excuses-aan-voor-mailonderzoek/.

30 J.R. Groen, Academische vrijheid: een juridische verkenning (dissertatie, Erasmus University Rotterdam, 2017), https://repub.eur.nl/pub/95506/ en https://www.advalvas.vu.nl/nieuws/academischevrijheid-groot-maar-er-zijn-spanningen. 
eisen van de overheid, soms ingrijpende besluiten om bijvoorbeeld opleidingen te stoppen of minder te financieren. Daarnaast lijkt onderzoek ook steeds vaker middels voorwaardelijke financiering in een bepaalde richting te worden gestuurd. Denk slechts aan de verdeling van middelen die het ministerie van Onderwijs, Cultuur en Wetenschap (OCW) heeft uitgetrokken voor versterking van de rechtswetenschap. Daarbij valt op dat faculteiten zelf maar mondjesmaat geld uit deze pot naar bestaande vakgebieden hebben gesluisd die in de verdrukking dreigen te komen waar het gaat om promotieplaatsen en dergelijke. De bulk van de middelen is juist gegaan naar onderzoekers die zich bezighouden met thema's die ook al door NWO en andere subsidieverstrekkers worden gefinancierd. ${ }^{31}$ Problematisch vanuit het perspectief van de onafhankelijkheid van de rechtswetenschap is daarbij dat er geen daadwerkelijk open competitie van ideeën heeft plaatsgevonden, omdat de thema's waarop kon worden ingeschreven in de praktijk soms al voorgeselecteerd waren. $^{32}$

Het gevolg hiervan is geweest dat het geld veelal juist niet is gegaan naar nationaalrechtelijk onderzoek op het gebied van het privaatrecht, staats- en bestuurs(proces)recht, strafrecht en fiscaal recht. Dit terwijl het onderwijs op deze hoofdgebieden van het recht qua onderzoeksfinanciering onder druk staat, maar qua onderwijs nog altijd de kern van het curriculum van de Nederlandse rechtenfaculteiten vormt. Dat academische onderwijs moet niettemin evengoed gevoed blijven worden door wetenschappelijk onderzoek, anders lopen wij steeds vaker het gevaar dat, zoals in de toeslagenaffaire is gebeurd, belangrijke ontwikkelingen in de rechtspraktijk door rechtswetenschappers over het hoofd worden gezien. ${ }^{33}$

\subsection{Onpartijdige rechtswetenschap?}

Nog opvallender is hoe weinig er over de onpartijdigheid van rechtswetenschappers wordt geschreven en gedebatteerd. ${ }^{34}$ Niet zolang geleden is er weliswaar commotie ontstaan naar aanleiding van een door het wetenschappelijk bureau van de partij Forum voor Democratie geïnstigeerd 'meldpunt voor linkse indoctrinatie' in

31 Daarover o.a. T. Barkhuysen \& J. van den Brink, 'Onderzoek naar Nederlands recht in de knel door internationalisering. Biedt het sectorplan Rechtsgeleerdheid uitkomst?', NJB 17 (2019): 464-467.

32 Mijn eigen faculteitsbestuur ging nog een stap verder door eerst een extern panel van deskundigen in te schakelen om de indiening van onderzoeksvoorstellen die mogelijk in aanmerking zouden komen voor subsidiëring te laten 'ranken' om vervolgens die ranking slechts gedeeltelijk over te nemen.

33 Vgl. op dit punt ook de kritiek van de voorzitter van de Afdeling bestuursrechtspraak op het feit dat veel bestuursrechtwetenschapper hun wijsheid over de gebreken in de rechtsbescherming pas gedeeld hebben nadat het rapport Ongekend onrecht van de commissie van Dam was verschenen. Zie B.J. van Ettekoven, “'Tussen wet en recht”. Reactie van de voorzitter van de Afdeling bestuursrechtspraak van de Raad van State op het rapport Ongekend onrecht van de Parlementaire ondervragingscommissie Kinderopvangtoeslag', NJB 2 (2021): 105.

34 Dat viel mij op bij het schrijven van deze publicatie: R.A.J. van Gestel, 'Onpartijdige rechtswetenschap?', RegelMaat nr. 1-2 (2018): 95-108. 
het onderwijs, ${ }^{35}$ waarbij door partijprominenten de stelling werd ingenomen dat er aan Nederlandse universiteiten sprake zou zijn van 'linkse ondermijning' ${ }^{36}$

Meer dan 800 docenten en onderzoekers tekenden hierop een open brief, waarin ze aangaven verontrust en gealarmeerd te zijn over dit soort uitspraken waarin wetenschappers verdacht worden gemaakt. ${ }^{37}$ In de brief wordt onder andere gewezen op een KNAW-advies over 'Vrijheid van wetenschapsbeoefening in Nederland', waarin wordt geconcludeerd dat het aan universiteiten wel meevalt met gebrekkige politieke diversiteit van wetenschappers. Van zelfcensuur zou geen sprake zijn en veel politicologen zouden bijvoorbeeld weliswaar links zijn, maar de verhoudingen bij andere disciplines, zoals bedrijfseconomie, zouden daarentegen juist weer andersom liggen. Als er al iets zou schuren dan zou het vooral de steeds grotere nadruk op valorisatie en maatschappelijke relevantie in het onderzoek zijn, die de academische vrijheid kan beperken omdat het de (financiële) ruimte voor ongebonden onderzoek beperkt. Voor het overige geen reden tot zorg, aldus de KNAW. ${ }^{38}$

Interessant is dat Stolker in een opiniestuk naar aanleiding van zijn Diësrede uit 2018 juist kanttekeningen plaatst bij het KNAW-advies. ${ }^{39}$ Hij benadrukt dat wetenschap vaak normatiever is dan we denken, zeker op het gebied van de humaniora. Daarbij wijst hij specifiek op de rechtswetenschap die niet alleen dicht op de politiek en praktijk zit, maar waarbij onderzoek ook soms in opdracht wordt verricht en dikwijls aanbevelingen worden verwacht voor 'beter recht' van wetenschappers:

'Want behalve een beschrijvende wetenschap is dat ook een prescriptieve wetenschap, met een nogal normatieve inslag. Enerzijds is er niet één waarheid omtrent het Nederlandse of Europese of internationale burgerlijk recht, strafrecht of fiscale recht. En anderzijds is het recht in een samenleving - het onderwerp waar juristen aan de academie zich mee bezig houden - uiteindelijk een balans tussen rechtszekerheid, doelmatigheid en rechtvaardigheid. En toch worden van rechtswetenschappers antwoorden verwacht die over voldoende argumentatieve draagkracht moeten beschikken: de objectivering van

35 Zie: https://www.renaissanceinstituut.nl/de-nieuwe-schoolstrijd-meldpunt-indoctrinatie-opscholen-en-universiteiten.

36 Mede van de hand van Paul Cliteur verscheen in 2019 de bundel Cultuurmarxisme, waarin onder meer wordt betoogd dat veel wetenschappers zich door een progressieve, postmoderne ideologie laten leiden en niet meer objectief zijn in hun werk. Zie: P. Cliteur \& J. Jansen (red.), Cultuurmarxisme: er waart een spook door het Westen (Soesterberg: Aspekt, 2019). Interessant is overigens dat diezelfde Cliteur in 2013 juist nog vond dat wetenschappers zowel ter linker-als rechterzijde juist steeds gematigder zouden zijn geworden en naar het midden zouden zijn opgeschoven. Zie F. Bolkestein, M. Fennema \& P. Cliteur, 'Aan universiteiten veel debat, maar gevoelige onderwerpen worden gemeden', de Volkskrant, 23 juni 2013.

37 De brief is te vinden op: https://openbriefacademici.wordpress.com/.

38 KNAW, Vrijheid van wetenschapsbeoefening in Nederland, Amsterdam, maart 2018 (https://www. knaw.nl/nl/actueel/publicaties/vrijheid-van-wetenschapsbeoefening-in-nederland).

39 C. Stolker, 'Vrijheid van wetenschap - drie steentjes in een rustige KNAW-vijver', Science Guide 23 mei 2018. 
standpunten voorbij alle politieke en maatschappelijke conflicten is een onderdeel van de rechtswetenschappelijke arbeid. ${ }^{40}$

Wat Stolker betreft, is het geen vanzelfsprekendheid dat die argumentatieve objectiviteit bij rechtswetenschappers altijd aanwezig is en daar zou hij best eens gelijk in kunnen hebben. Klachten en zorgen over onvoldoende objectief juridisch onderzoek zijn er voldoende. Zo beweerde Nieuwenhuis in een interview in 2007 reeds dat het geregeld voor zou komen dat in proefschriften onwelgevallige jurisprudentie gewoon wordt weggelaten. ${ }^{41}$ Vaak zou daarbij niet worden uitgelegd waarom bepaalde arresten niet in het onderzoek zijn verwerkt. ${ }^{42}$ Of deze observatie voor de gehele breedte van het juridische onderzoek opgaat, is nog nooit systematisch onderzocht. Interessant is niettemin bijvoorbeeld dat Wijntjens in haar proefschrift over de rol van excuses in het aansprakelijkheidsrecht met behulp van codering en structured content analysis van meer dan 4000 uitspraken ${ }^{43}$ heeft aangetoond dat veelvoorkomende normatieve stellingnames in de literatuur, die beweren dat het aanbieden van excuses door de rechter zou kunnen worden gezien als het erkennen van aansprakelijkheid, op drijfzand berusten. ${ }^{44}$

Dit laatste geeft op zijn minst te denken over de wijze waarop meerdere collegawetenschappers tot tegengestelde conclusies kwamen. Niet alleen onderzochten zij mogelijk minder uitspraken, maar de vraag is ook hoe zij die uitspraken hebben geselecteerd en geanalyseerd. Wordt er inderdaad niet te vaak aan cherry picking gedaan en zou het zo kunnen zijn dat enkele afwijkende uitspraken soms worden uitvergroot? Het roept de vraag op of rechtswetenschappers in de woorden van Schoordijk niet teveel 'resultaatvoetbal' spelen? ${ }^{45}$ Beginnen zij hun onderzoek niet al te vaak met een idee over waar ze uit willen komen om daar vervolgens argumenten en bewijs bij te zoeken? Anders gezegd: hoeveel ruimte laat de betogende stijl van doctrinalisten, in combinatie met een dikwijls weinig systematische methode van bronnenonderzoek, ${ }^{46}$ voor een zoektocht naar tegenbewijs en tegenargumenten voor de eigen normatieve visie op het geldende recht? ${ }^{47}$

Welke rol speelt bovendien het feit dat op tal van rechtsgebieden - denk aan het milieurecht, personen- en familierecht en gezondheidsrecht - theorie en praktijk

40 Ibid.

41 Daarover ook reeds: J.B.M. Vranken, 'Als een arrest niet bevalt, laten wij het gewoon weg', in Ex libris Hans Nieuwenhuis, ed. A.G. Castermans e.a. (Deventer: Kluwer, 2009), 77-93.

42 H. Nieuwstadt \& E. van Schagen, 'De juristen moeten de vragen stellen', Ars Aequi (2007): 923-924.

43 P.W.J Verbruggen (red.), Methoden van systematische rechtspraakanalyse (Den Haag: Boom juridisch, 2021).

44 L.A.B.M. Wijntjens, Als ik nu sorry zeg, beken ik dan schuld? (Den Haag: Boom juridisch, 2020).

45 R. de Graaff \& E. Verheul, 'Zelfs met het meest krakkemikkige wetboek kan ik nog werken', Ars Aequi (2015): 70.

46 Zie over die methode van bronverwijzing o.a. M. Snel, Meesters over bronnen (Den Haag: Boom juridisch, 2016) en vergelijk voor een mooi voorbeeld van de betekenisloosheid van veel bronverwijzingen ook: W.H. van Boom, Door meten tot weten - Over rechtswetenschap als kruispunt (Den Haag: Boom Juridische uitgevers, 2015).

47 J.B.M. Vranken, 'Als een arrest ons niet bevalt, laten wij het gewoon weg', in Ex Libris Hans Nieuwenhuis, red. A.G. Castermans e.a. (Deventer: Kluwer, 2009) 88. 
nauw met elkaar verweven zijn, omdat veel van die wetenschappers zelf met een been in de praktijk staan en bovendien het overheidsbeleid vaak nauwgezet volgen, en het recht bovendien sterk moreel geladen is? Zo hebben Coomans, Grünfeld en Kamminga over het mensenrechtendiscours aangegeven dat nogal wat wetenschappers op dit gebied voormalige activisten zijn die geloven in de positieve kracht van mensenrechten, waarbij hun doel is om het respect voor deze fundamentele rechten te bevorderen, maar die dikwijls weinig aandacht hebben voor het feit dat mensenrechtenstandaarden geen doel op zich zijn, maar een middel om het respect voor de menselijke waardigheid te bevorderen. Zij zouden zich dikwijls onvoldoende realiseren dat deze 'fundamentele' rechten ook vaak compromissen zijn tussen staten die bepaald niet perfect zijn en dat de afkondiging van nieuwe rechten en de instelling van allerlei nieuwe internationale instituties zeker niet automatisch betekent dat er ook daadwerkelijk op de grond iets verandert. ${ }^{48}$

\section{Wat zeggen de regels?}

Hoeveel houvast bestaat er eigenlijk voor rechtswetenschappers met betrekking tot de vraag welke normen voor hen gelden op het gebied van onafhankelijkheid en onpartijdigheid? Wettelijke normen die de onafhankelijkheid en onpartijdigheid van (rechts)wetenschappers moeten beschermen zijn er nauwelijks. Voor zover ze er al zijn, zijn ze bovendien vaak ook nog eens boterzacht. Vergelijk artikel 9.19, lid 2 van de Wet op het hoger onderwijs en wetenschappelijk onderzoek (WHW):

'De hoogleraren zijn bij uitstek verantwoordelijk voor de ontwikkeling van het hun toegewezen wetenschapsgebied en voor de inhoud van het te geven onderwijs op dat gebied, onverminderd de bevoegdheid van het bestuur van de opleiding, bedoeld in artikel 9.17.'

Je bent als hoogleraar verantwoordelijk voor je vakgebied, maar als een faculteit bijvoorbeeld besluit om bepaalde leerstoelen simpelweg te schrappen, zoals recentelijk gebeurde aan de Erasmus Universiteit met de algemene leerstoelen staats- en bestuursrecht, dan helpt een protestbrief waarin wordt verwezen naar deze wettelijke normen in elk geval niets. ${ }^{49}$ De enige rechten die in artikel 9.19 WHW te vinden zijn, zijn het feit dat je als hoogleraar de titel professor mag voeren en dat je tot vijf jaar na je (eervol) ontslag nog als promotor op mag treden. Dit laatste lijkt echter eerder een regel om de rechten van promovendi te waarborgen die voor het emeritaat van hun promotor aan een promotietraject zijn begonnen dan om hoogleraren een reddingsboei toe te werpen. Zo mogelijk nog vager zijn de normen uit de Nederlandse gedragscode wetenschappelijke integriteit. Deze code bepaalt voor zover hier relevant:

49 Zie: https://www.uva.nl/binaries/content/documents/personalpages/o/r/r.ortlep/nl/downloads/ downloads/assets/asset. 
'Onafhankelijkheid houdt onder andere in dat men zich in de keuze van de methode, bij de beoordeling van de data en in de weging van alternatieve verklaringen, maar ook bij het beoordelen van onderzoek of onderzoeksvoorstellen van anderen, niet laat leiden door buiten-wetenschappelijke overwegingen (bijvoorbeeld overwegingen van commerciële of politieke aard). Aldus geformuleerd omvat onafhankelijkheid ook onpartijdigheid. Onafhankelijkheid is in elk geval vereist bij de opzet en uitvoering van en rapportage over het onderzoek; bij de keuze van het onderzoeksobject en van de onderzoeksvraag is onafhankelijkheid niet altijd nodig' [curs. RvG]. ${ }^{50}$

Niet alleen biedt dit beginsel, mede door de wijze van formuleren, weinig houvast, maar belangrijker is dat wat aan de ene kant wordt verlangd, zoals onafhankelijkheid bij de keuze van de methode en dergelijke, aan de andere kant weer lijkt te worden weggegeven door onder andere te stellen dat onafhankelijkheid bij de keuze van de onderzoeksvraag niet altijd nodig is. Wat betekent 'niet altijd' hier? Wanneer niet dan? En waarom is de formulering van de onderzoeksvraag eigenlijk geen onderdeel van de methode? Daar komt nog bij dat onafhankelijkheid en onpartijdigheid in deze bepaling - anders dan in de gedragscode wetenschappelijke integriteit van onze zuiderburen - tegelijkertijd weer op een hoop worden gegooid, terwijl daartussen ongetwijfeld raakvlakken bestaan maar het waarborgen ervan toch ook vaak verschillende eisen stelt. ${ }^{51} \mathrm{Bij}$ onafhankelijkheid gaat het namelijk in de eerste plaats om het beschermen van rechtswetenschappers tegen onheuse beïnvloeding of druk van binnen of buiten de universiteit. Onpartijdigheid heeft veeleer betrekking op het feit dat wetenschappers zich bij het geven van onderwijs en het uitvoeren van onderzoek niet laten beïnvloeden door hun eigen persoonlijke voorkeuren, sympathieën, belangen of vooringenomenheden.

Bij de kernwaarde onpartijdigheid is veel meer dan bij het waarborgen van de onafhankelijkheid sprake van een schemergebied. De VSNU-gedragscode bevat hier enerzijds tal van voorschriften die een hoog 'opendeurgehalte' bezitten, zoals: hanteer wetenschappelijke methoden, zorg dat bronnen controleerbaar zijn, doe recht aan alle verkregen onderzoeksresultaten enzovoort, maar biedt anderzijds ook niet of nauwelijks houvast waar het gaat om de gedragsregels die hebben te gelden en die ook gehandhaafd moeten worden. De normen zijn zeker geen onzin, maar ten eerste behoeven die regels vaak concretisering en duiding waar het gaat om de praktische toepassing. Ten tweede, en nog belangrijker, is dat we, voor we aan de handhaving van regels kunnen toekomen, eerst een onderwijs- en onderzoeksklimaat moeten scheppen waarin een open gedachtewisseling en het elkaar weder-

50 Nederlandse gedragscode wetenschappelijke integriteit 2018, hfst. 2, onder 4 (https://www.vsnu. $\mathrm{nl} /$ files/documenten/Nederlandse\%20gedragscode\%20wetenschappelijke\%20integriteit\%202018. pdf).

51 Veel beter komt dat tot uitdrukking in de ethische code van het wetenschappelijk onderzoek in België, Brussel 2009, 9-10, waarin onafhankelijkheid en onpartijdigheid juist nadrukkelijk onderscheiden worden. Zie www.belspo.be/belspo/organisation/publ/pub_ostc/Eth_code/ethcode_nl. pdf. 
zijds aanspreken op een gebrek aan onpartijdigheid mogelijk is. Dat erkent de gedragscode overigens ook. Zo luidt regel 10 van $\S 4.3$ :

'Zorg voor een open, veilige en inclusieve onderzoekscultuur waarin onderzoekers: a. de normen voor goede onderzoekspraktijken met elkaar bespreken, b. elkaar op het naleven van die normen aanspreken, en c. bij een redelijk vermoeden van niet-naleven van die normen bereid zijn dit te melden bij de commissie of functionaris als bedoeld onder 21 (RvG: lees het CWI) of een vertrouwenspersoon als bedoeld onder 20.52

De vraag is alleen: wie doet dat en hoe precies? 'De instelling', zegt de code. Het zullen echter uiteindelijk personen binnen de instelling moeten zijn. Dan geldt: wie selecteert deze mensen, hoeveel tijd en ruimte krijgen zij en hoe deskundig, gemotiveerd en geëquipeerd zijn ze? Bovendien: hoe organiseer je een open, veilige en inclusieve onderzoekscultuur? Men kan wel allerlei protocollen en instructies maken, maar juristen weten dat papier geduldig is en dat normen niet automatisch nageleefd worden. Ook normen als zorg voor passende begeleiding voor jonge onderzoekers klinken verstandig, maar wat hebben deze onderzoekers daar precies aan als het mis gaat in die begeleiding? De ervaring leert dat met name jonge wetenschappers en mensen met een tijdelijke aanstelling vaak niet naar vertrouwenspersonen en klachtinstanties durven stappen uit angst voor repercussies. ${ }^{53}$

\section{Onafhankelijkheid en onpartijdigheid vergen deels verschillende waar- borgen}

Nu gebrekkige onafhankelijkheid en partijdigheid in de rechtswetenschap tot verschillende problemen kunnen leiden, lijkt het zaak om de waarborgen daartegen ook daarop af stemmen.

\subsection{Bescherming van de onafhankelijkheid}

Bij onafhankelijkheid gaat het primair om de bescherming van de positie van de onderzoeker en de mate waarin deze hem of haar vrijwaart van onheuse beïnvloeding en druk. Denk op dit punt bijvoorbeeld aan de idee van tenure, zoals te vinden in de VS, waar de American Association of University Professors al in 1940 een verklaring heeft opgesteld waarin belangrijke beginselen op het punt van de academische vrijheid zijn neergegelegd. Tenure wordt daarin gedefinieerd als:

52 Paragraaf 4.3 gaat in zijn geheel over de onderzoekscultuur en wijst bijvoorbeeld ook op het belang van heldere instructies, protocollen of andere middelen die de onderzoeker steun en inzicht bieden in wat een goede onderzoekspraktijk binnen de discipline(s) en instelling impliceert: https://www. vsnu.nl/files/documenten/ Nederlandse\%20gedragscode\%20wetenschappelijke\%20integriteit\%20 2018.pdf.

53 S.P.J.M. Horbach, To Spill, Filter and Clean: On problematic research articles, the peer review system, and organisational integrity procedures (PhD diss., Nijmegen, 2020) 217 e.v. (https://www.nrin.nl/ docman/theses/3-dissertation-serge-horbach/file) en S.P.J.M.Horbach, E. Breit, W. Halffman \& S. Mamelund, 'On the Willingness to Report and the Consequences of Reporting Research Misconduct: The Role of Power Relations', Science and Engineering Ethics 26 (2020): 1595-1623. 
'After the expiration of a probationary period, teachers or investigators should have permanent or continuous tenure, and their service should be terminated only for adequate cause, except in the case of retirement for age, or under extraordinary circumstances because of financial exigencies. ${ }^{54}$

De kerngedachte achter tenure is dat aan wetenschappers na een proefperiode waarin zij laten zien een eigen onderzoeksagenda te kunnen opbouwen, over voldoende onderwijsvaardigheden beschikken, externe zichtbaarheid weten te bewerkstellen en ook aantonen bepaalde administratieve of maatschappelijke diensten te kunnen en willen verlenen, een permanente positie wordt gegund. De bedoeling daarvan is de academische vrijheid van wetenschappers te beschermen tegen interne en externe beïnvloeding en ook zeggenschap binnen de universiteit te verstevigen. Tenured professors hebben doorgaans niet alleen inspraak in het facultaire beleid, maar hun positie biedt ook bescherming tegen ontslag vanwege een kritische houding of het publiceren van onwelgevallig onderzoek dat tot commotie in politiek of media leidt. Een soortgelijke bescherming, die overigens ook wel nadelen heeft - denk aan het tamelijk langdurige tenure traject in de VS met allerlei tussentijdse beoordelingen waar getalenteerde jonge wetenschappers dan verplicht doorheen moeten ${ }^{55}$ - kennen wij niet. Op zichzelf hoeft dat geen probleem te zijn indien er afdoende alternatieve waarborgen zijn, maar is dat eigenlijk zo?

Deze bijdrage opende met het dubbelepettenprobleem in de fiscaliteit dat de afgelopen jaren herhaaldelijk is opgekomen. Waarom zouden wij niet hardere (desnoods wettelijke) regels kunnen maken over de benoemingsprocedures voor bijzondere leerstoelen? Denkbaar is bijvoorbeeld om als gouden regel op te nemen dat rechtenfaculteiten geen werknemers van sponsoren van bijzondere leerstoelen benoemen op de betreffende leerstoel. Sponsoren die de beste hoogleraren op een door hen mede bekostigde leerstoel benoemd willen zien en iedere schijn van belangenverstrengeling willen vermijden, zouden daar geen moeite mee mogen hebben. Indien dat zou betekenen dat de 'markt' voor bijzondere externe gefinancierde leerstoelen instort dan zou dat wat mij betreft veelzeggend zijn. Waar het gaat om de onafhankelijkheid van jonge (aspirant-)rechtswetenschappers, zoals promovendi, postdocs en andere medewerkers op tijdelijke contracten, zijn andere beschermingsconstructies mogelijk. Omdat Nederland niet rijp lijkt voor een tenure model naar Amerikaans voorbeeld zouden we ook kunnen nadenken over versteviging van het bestaande versplinterde systeem van klachtbehandeling aan universiteiten met vertrouwenspersonen, klokkenluidersregelingen, commissies voor ongewenst gedrag, commissies voor wetenschappelijke integriteit en ombudspersonen. Nu hierboven (par. 4) is aangegeven dat wetenschappers uit deze groepen vaak niet naar bestaande klachtinstanties durven stappen uit angst voor repercussies, is het misschien zaak het vertrouwen in deze klachtinstanties zelf te verstevigen. Dit kan door hen een meer zichtbare onafhankelijke positie te geven waarin 
voor de buitenwacht ook duidelijk is wat de bevoegdheden van deze instanties zijn en over welke mogelijkheden zij beschikken om klagers zelf te beschermen tegen represailles.

Omdat uit onderzoek van de FNV en de Vawo, de vakbond voor de wetenschap (thans Aob), is gebleken dat vier op de tien universiteitsmedewerkers last heeft van pesten, roddelen, uitsluiting en machtsmisbruik, ${ }^{56}$ lijkt het zaak om de cao-afspraken, dat per 1 juli 2021 iedere universiteit over een ombudspersoon dient te beschikken, strikt op te volgen. Daarbij rijst de vraag of het niet beter zou zijn deze ombudsfunctie bij de Nationale ombudsman onder te brengen in de vorm van een landelijk 'Wetenschapsombudspersoon'. Deze zou de wettelijke bevoegdheid kunnen krijgen om informatie te vergaren, betrokken partijen te horen, zelf onderzoek te verrichten en ook de opvolging van aanbevelingen voor diens rekening te nemen. ${ }^{57}$

Met zo'n landelijke Wetenschapsombudspersoon wordt een duidelijk signaal afgegeven aan universiteitsbesturen dat het niet langer mogelijk is om vanuit het perspectief van het voorkomen of beperken van imagoschade zoveel mogelijk klachten informeel af te doen opdat 'de vuile was binnenskamers blijft' zonder dat dit noodzakelijk veel garanties biedt voor klagers. De positie van een parttime ombudsman in loondienst, die benoemd wordt door het College van Bestuur en die aanbevelingen doet aan datzelfde college dat deze vervolgens naast zich neer kan leggen, lijkt namelijk te weinig vertrouwenwekkend om medewerkers, die zich vaak in een afhankelijkheidsrelatie bevinden, over de streep te treken om integriteitsschendingen, waaronder inbreuken op hun onafhankelijkheid, te melden. Dit geldt temeer nu wetenschappers naar aanleiding van publieke optredens en activiteiten op sociale media steeds vaker te maken krijgen met bedreiging, intimidatie en haatreacties zowel van binnen als buiten de eigen organisatie. ${ }^{58}$

\subsection{Bescherming van de onpartijdigheid}

Interessant is dat een kernbegrip om de onpartijdigheid van wetenschappers te borgen niet één keer expliciet wordt benoemd in de Nederlandse gedragscode wetenschappelijke integriteit. Dan heb ik het over 'kritiek'. Het belangrijkste dat (rechts)wetenschappers kunnen doen om hun eigen persoonlijke voorkeuren, vooringenomenheden, politieke sympathieën en dergelijke onder controle te houden en te zorgen dat ze moeilijker doorsijpelen in het eigen onderwijs en onderzoek is namelijk het organiseren van kritiek en dus tegenspraak. ${ }^{59}$ Dat dient niet alleen aandacht te krijgen in de vorm van peer review aan de achterkant, maar juist veel eerder in het proces bij de voorbereiding van colleges, lezingen, publicaties,

56 Zie: https://www.aob.nl/nieuws/universiteitspersoneel-voelt-zich-onveilig/.

57 Verschillende partijen hebben daar ook voor gepleit. Zie: https://www.scienceguide.nl/2021/02/ kamer-wil-een-onafhankelijkere-ombudsfunctie-op-de-universiteit/.

58 Zie: https://www.parool.nl/nederland/universiteiten-nemen-maatregelen-tegen-bedreigingwetenschap pers b0ecb7e8/?referrer=https\%3A\%2F\%2Fwww.google.com\%2F en https://www. scienceguide.nl/2021/07/wetenschappers-zwichten-voor-intimidatie/.

59 R.A.J. van Gestel, 'Tegenspraak in de rechtswetenschap', Ars Aequi (2017): 878-885. 
onderzoeksvoorstellen enzovoort. Osterloh en Frey hebben er terecht op gewezen dat moderne universiteiten te veel nadruk leggen op wetenschappelijke outputcontrole via citatiemeting, rankings, visitaties, maar juist te weinig oog hebben voor inputcontrole in de vorm van zorgvuldige selectie, training en socialisatie van aspirant-wetenschappers:

'If neither output control nor process control works sufficiently well, input control has to be applied. This kind of control is usually used when easy-tomeasure outputs are not available [...] To become a member of a profession, it is necessary to pass long-term education, selection, and self-selection, which ensure that one has deeply internalized professional norms as intrinsic values. Institutional rituals confirm these norms in order to signal that they have become part of the professional identity. The aim of the socialization and selection process is to induce professionals to follow these norms even if there are no controls and sanctions. ${ }^{60}$

Ook hier laten rechtenfaculteiten momenteel kansen liggen. Wie goede wetenschappers wenst die integer werken moet in de 'jeugdopleiding' beginnen. Dit betekent dat studenten vanaf het eerste jaar van de studie getraind moeten worden om na te denken over zaken als wat betekent het om wetenschappelijk te werken en waarin verschilt dat van wat bijvoorbeeld een rechter, advocaat of bijvoorbeeld wetgevingsjurist doet? Welke waarden en normen spelen in de wetenschap een rol? Welke vormen van 'bias' bestaan in de wetenschap en waarom vormen ze een probleem ${ }^{61}$ Welke methodologische spelregels gelden voor verschillende typen van rechtswetenschappelijk onderzoek en welke risico's loop je als je je daar niet aan houdt?

Dit is iets meer en iets anders dan thans veelal gebeurt in het juridisch onderwijs. Zo gaat het er niet eerst en vooral om dat je studenten erop wijst dat er zoiets als een citatieleidraad is die aangeeft hoe je netjes verwijst naar wetgeving, jurisprudentie en literatuur en dat plagiaat verboden is. Veel belangrijker is dat je begint bij de verschillende functies die bronverwijzingen kunnen hebben, zoals het onderbouwen van een claim, het schetsen van de state of the art of het laten zien dat er andere opvattingen bestaan over jouw uitleg van een regel. ${ }^{62}$ Dat betekent ook dat uitgelegd moet worden waarom moet worden opgepast met het knippen en plakken van teksten van anderen en hoe gemakkelijk dat mis kan gaan in onze gedigitaliseerde wereld. Studenten zouden bovendien vanaf het begin van de studie zelf

60 B. Frey \& M. Osterloh, 'Ranking Games', Evaluation Review 39, no. 1 (2015): 102-129, op 115.

61 Zie voor een praktisch overzicht o.a.: A. Gordon, 'Better Than Our Biases: Using Psychological Research to Inform Our Approach to Inclusive, Effective Feedback', Clinical Law Review 195 (2021), Duke Law School Public Law \& Legal Theory Series No. 2021-28, Available at SSRN: https://ssrn. com/abstract=3777546 en E. Cook, We All Do It: How Bias Informs Legal Research and Teaching, University of Washington Information School Seattle, Washington 19 May 2016. Zie: https://depts. washington.edu/uwlawlib/wordpress/wp-content/uploads/2018/01/Cook2016.pdf.

62 Zie over die verschillende functies ook reeds R.A.J. van Gestel \& J.B.M. Vranken, 'Rechtswetenschappelijke artikelen. Naar criteria voor methodologische verantwoording', NJB (2007): 1448-1461. 
onderzoek moeten leren uitvoeren met een oplopende moeilijkheidsgraad. Daarmee kan worden begonnen in de bachelor en eindigend in de research masters en promovendi-opleidingen. Naast aandacht voor wetenschapsfilosofie en methodologie is het vooral ook van belang dat individuele feedback wordt gegeven op de onderzoeksproducten van studenten en dat kritisch meegekeken wordt naar de wijze van aanpak van het onderzoek. ${ }^{63}$ Daarin kunnen ook zaken worden meegenomen zoals het wijzen van studenten op vooringenomenheden. Hierbij is het cruciaal is om studenten te confronteren met de vraag of er ook andere relevante denkrichtingen in het onderzoek mogelijk zijn. Een kernvraag die iedere wetenschapper zich bij ieder onderzoek herhaaldelijk zou moeten stellen luidt immer: zou ik ook ongelijk kunnen hebben?

Kritiek komt doorgaans niet vanzelf en moet georganiseerd worden. Het vergt een proces van socialisatie en gewenning - leren dat onzekerheid en tegenspraak erbij hoort en je beter maakt - maar vooral ook van vertrouwen en openheid. Dit is ook een opdracht voor 'de instelling' waarvoor kritiek organiseren evengoed niet vanzelfsprekend is. Het verlangt bijvoorbeeld een benoemingenbeleid waarbij faculteiten niet enkel kijken naar kwaliteit, maar ook naar diversiteit opdat een vakgroep, sectie, onderzoeksschool enzovoort geen groep van gelijkgestemden wordt. Het vergt echter tevens een faciliterende houding van bestuurders die creativiteit herkennen en open staan voor verandering. Of zoals de medeoprichter van Apple, Steve Jobs, het ooit omschreef:

'It doesn't make sense to hire smart people and tell them what to do; we hire smart people so they can tell us what to do.'64

Dit betekent zeker niet dat wetenschappers in alles hun zin moeten krijgen, maar wel dat ze met hun creativiteit kunnen woekeren en niet nodeloos belemmerd worden door organisatorische hokjesgeest, onderzoeksprogrammatische dwang en bureaucratische verantwoordingszucht. Daar staat tegenover dat het waarborgen van de onpartijdigheid in onderwijs en onderzoek bijvoorbeeld ook concurrentie van ideeën veronderstelt. Daarvoor is het organiseren van peer review-processen essentieel. Om tunnelvisie, slordig onderzoek en vooringenomen standpunten tegen te gaan, is het van belang dat er binnen onderwijs- en onderzoeksgroepen inhoudelijk kritisch naar elkaars bijdragen wordt gekeken. Dit geldt temeer nu van een onafhankelijke externe peer review-cultuur binnen de rechtswetenschap nog onvoldoende sprake is. Zoals ik reeds eerder heb verdedigd, zouden faculteitsbestuurders in overleg met redacties van tijdschriften en uitgevers hier het voortouw in moeten nemen. ${ }^{65}$

63 Vgl. ook K. Schuyt, 'De wil om dingen uit te zoeken: de wetenschappelijke houding', Steunberen van de samenleving (Amsterdam: Amsterdam University Press, 2006), 240.

64 Steve Jobs, 1996, Fresh Air radio interview by Terry Gross, npr.org www.npr.org/2011/10/06/141115121/ steve-jobs-computer-science-is-a-liberal-art, audio 26:30/31:05.

65 Meest recentelijk in R.A.J. van Gestel, 'Revitalisering van juridisch-dogmatisch onderzoek. Expliciteren van het impliciete’, NJB 4 (2021): 294-295. 


\section{Conclusie}

Deze bijdrage is begonnen met de constatering dat rechtswetenschappers vanouds terecht veel aandacht hebben voor de onafhankelijkheid en onpartijdig van de rechter, maar niet voor die van henzelf. De vraag is of dat louter te rechtvaardigen valt door de verschillen tussen de rechter en de rechtswetenschapper. Mijn voorlopige conclusie is dat dit niet het geval lijkt - hoewel er niet of nauwelijks empirisch onderzoek is naar de omvang van de problemen bij rechtswetenschappers - en dat hun positie in bepaalde opzichten zelfs kwetsbaarder is dan die van de rechter. Zo hebben rechtswetenschappers geen natuurlijke tegenstanders, zoals procespartijen in een geding voor de rechter die wel hebben, is er geen cultuur van onafhankelijke externe peer review, is er vaak geen hoger beroep mogelijk tegen beslissingen van tijdschriftredacties of uitgevers om onderzoek bijvoorbeeld niet te publiceren, liggen de meeste rechtswetenschappers niet onder het vergrootglas van de media en, belangrijker nog, zit de rechtswetenschap vol met afhankelijkheidsrelaties tussen promotoren en promovendi, auteurs en uitgevers en onderzoeksaanvragers en sponsoren enzovoort. Daar komt nog bij dat door de huidige nadruk op maatschappelijke impact ook rechtswetenschappers nog dichter op de rechtspraktijk worden gedrukt, terwijl zij - anders dan wetenschappers in de hard sciences - eigenlijk nooit een probleem hebben gehad met tekortschietende maatschappelijke relevantie, maar juist wel met het transparant maken van hun wetenschappelijke relevantie. De WODC-affaire heeft bovendien nog eens aangetoond dat onderzoek in opdracht van beleidsmakers ook risico's in zich draagt waar het gaat om het behoud van de eigen onafhankelijkheid en onpartijdigheid.

Vervolgens heb ik mede aan de hand van voorbeelden aangetoond dat er ook voor rechtswetenschappers wel degelijk reële bedreigingen van hun onafhankelijkheid en onpartijdigheid op de loer liggen, hoewel veel van problemen die in de openbaarheid komen vaak al snel worden afgedaan als incidenten. Sommige zaken zijn evenwel niet zonder meer terug te brengen tot een ongelukkige samenloop van omstandigheden. Zo heeft Groen op basis van zijn dissertatieonderzoek verdedigd dat universitaire bestuurders ogenschijnlijk steeds meer invloed proberen uit te oefenen op opleidingen en op de richting van het wetenschappelijk onderzoek. ${ }^{66}$ Aan de andere kant weten we ook uit onderzoek dat met name wetenschappers die een tijdelijk contract hebben, zoals promovendi, post docs en toegevoegd docenten, problemen op het vlak van de wetenschappelijke integriteit vaak niet durven melden uit angst voor represailles, terwijl uit enquêtes blijkt dat vier op de tien universiteitsmedewerkers last zegt te hebben van pesten, roddelen, uitsluiting en machtsmisbruik. Dat lijkt toch op zijn minst reden om eens wat grondiger naar allerlei integriteitsproblemen, zoals aantastingen van de onafhankelijkheid, de onpartijdigheid en de academische vrijheid meer in het algemeen, te gaan kijken om te bezien wat ertegen gedaan kan worden. 
Vastgesteld is ook dat de bescherming van de onafhankelijkheid en onpartijdigheid van rechtswetenschappers, in tegenstelling tot die van de rechter, zwaar leunt op zelfregulering, terwijl het nog maar de vraag is of deze zelfregulering nu wel altijd zo effectief is. Het feit dat niet alleen het dubbelepettenprobleem, maar ook de discussie rond bijklussende eenpetters bij herhaling terugkomt, zou reden tot gezonde twijfel moeten zijn. Daar komt bij dat de Nederlandse gedragscode wetenschappelijke integriteit onafhankelijkheid en onpartijdigheid teveel op een hoop lijkt te gooien, terwijl het qua bescherming toch deels om sterk verschillende zaken gaat. Waar onafhankelijkheid vooral raakt aan de (rechts)positie van wetenschappers en de bescherming tegen externe beïnvloeding en druk vanwege andere dan wetenschappelijke belangen, gaat het er bij onpartijdigheid veeleer om de rechtswetenschapper te wapenen tegen diens eigen vooringenomenheden, voorkeuren en politieke sympathieën.

Voor wat betreft het eerste zou, zolang het niet mogelijk is de rechtspositie van wetenschappers te versterken, op zijn minst gekozen kunnen worden voor meer vertrouwenwekkende onafhankelijke klachtloketten en een of meer Wetenschapsombudslieden die niet in loondienst zijn bij een universiteit en die wettelijk geregelde onderzoeksbevoegdheden hebben en ook de opvolging van aanbevelingen kunnen monitoren. Betreffende de borging van de onpartijdigheid van rechtswetenschappers zou het goed zijn om methodologie en integriteit een verplicht onderdeel te maken van het curriculum waarin studenten al vroeg kennis maken met ethische dilemma's en ook wordt geleerd hoe om te gaan met kritiek en tegenspraak op bijvoorbeeld eigen onderzoeksproducten. Ten slotte zouden we werk moeten maken van meer systematische kwaliteitscontrole op rechtswetenschappelijk onderzoek. Daarin hoort plaats te zijn voor zaken als expliciete vermelding van het ontbreken van belangenconflicten bij auteurs, scherper onderscheid tussen vakpublicaties en wetenschappelijke publicaties en duidelijkere eisen op het gebied van het expliciteren van de methode van onderzoek. 